\title{
Probing the potentiality of the defoliator Cricula trifenestrata Helfer silk: a revisit
}

\author{
Hemachandran Hridya ${ }^{1 *} \mathbb{D}$, Lopamudra Guha', Mahashankar Mazumdar² ${ }^{1}$ B. N. Sarkar ${ }^{1}$, Soni Vijayakumar ${ }^{3}$ and \\ P. Borpuzari ${ }^{1}$
}

\begin{abstract}
Background: Transformation of pest to valuable product is considered to be a noteworthy innovation. This article explores the potentiality of wild silkworm Cricula trifenestrata Helfer for sustainable development towards human livelihoods.

Results: The innate characteristics of this silkworm with robust rearing capacity have bestowed various aspects of biomaterials with special context to diversification of wild silk products. Views on challenges, prospects and the enigma of converting a pest to beneficial product are also unraveled. Exploration on utmost utilization of raw silk, scope for varied byproduct from silk waste may contribute a ray of hope for income generation to the rural population.
\end{abstract}

Conclusion: With suitable plantation and congenial climatic conditions for rearing Cricula trifenestrata may serve as an alternative wild silk in contributing to the country's wild raw silk production.

Keywords: Wild, Silkworm, Cocoon, Cricula, Pest, Product, Silk

\section{Background}

Wild/Vanya silkworm confers to non-mulberry silkworm which comprises Antheraea mylitta, Antheraea proylei, Antheraea assamensis and Samia ricini which are commercially exploited in India. In other countries wild silkworms which are commercially exploited includes Gonometa, Hylaphora, Antheraea yamamai, Antheraea pernyi etc. In the present scenario, India's vanya raw silk production is around 10,581 MT (29.5\%) against the country's total production of 35,820 MT for the year 2019-20. In 2020-21, despite of covid-19 pandemic 33,739 MT of Raw silk was produced in which 9879 MT $(29.2 \%)$ is contributed by vanya silk (Source Central Silk Board, Bangalore, India). There are numerous wild silkworm in India, which are least concerned for its probable productivity. An attempt is made to discuss

\footnotetext{
*Correspondence: hridya004@gmail.com

${ }^{1}$ Muga Eri Silkworm Seed Organisation, Ministry of Textiles, Central Silk

Board, Guwahati, Assam, India

Full list of author information is available at the end of the article
}

about a common pest which can be transformed into a commercial product with scientific and technological intervention.

Cricula trifenestrata Helfer is a wild Lepidopteron sericigenous moth known for its lustrous golden cocoon. The Genus Cricula was proposed by Walker in 1855. Capt. Jenkins and Helfer coined the species trifenestrata due to the presence of 3 windows like structure in the forewing as represented in Fig. 1 (Tikader et al. 2014; Kaleka et al. 2018). It is invariably considered as a pest for Antherea assamensis i.e., muga silkworm as it depletes the foliage by feeding thereby affecting the Effective Rearing Rate (ERR) of Muga silkworm. They infect a wide range of host plants namely Mangifere indica, Persea bomycina, Anacardium occcidentale, Arachis hypogeal Cinnamomum cassia, litchi cheinensis, Machilus odoratissima and Camellia sinensis (Ahmed et al 2012; Gharde and Chaudhuri 2018; Narang and Gupta 1979; Tikader et al. 2014). Host diversity of Cricula trifenestrata is detailed in (Table 1). Cricula trifenestarata is widely distributed in South Asian countries (Fig. 2). Cricula trifenestrata is 
a)

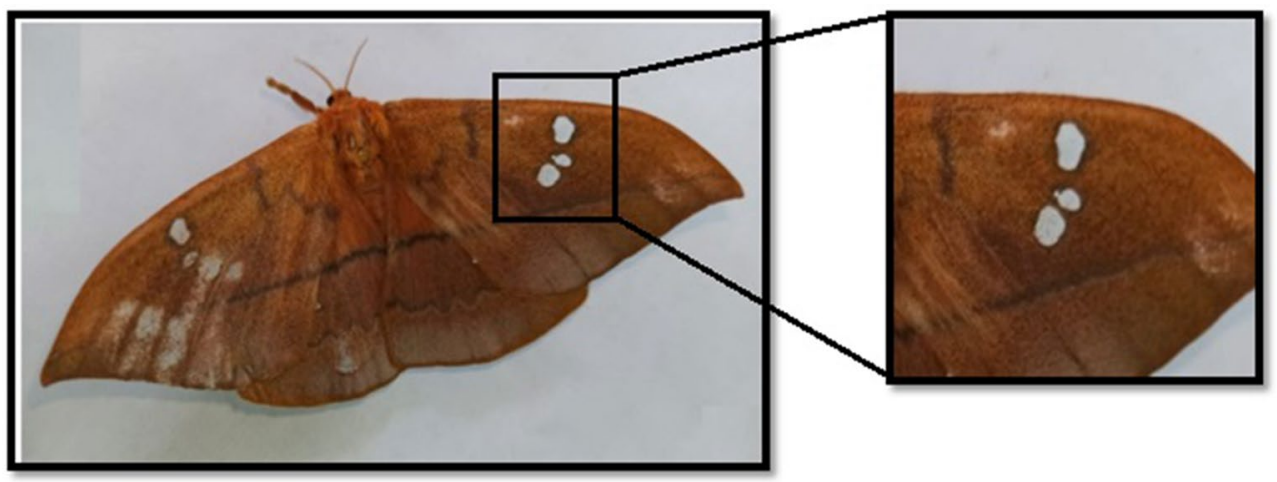

b)

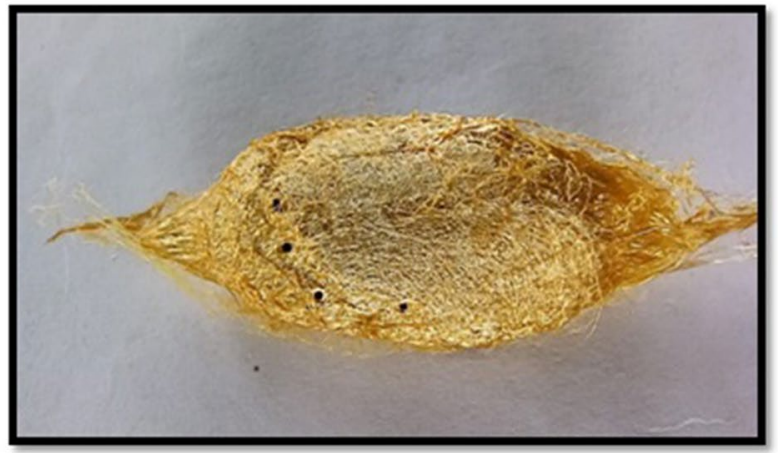

Fig. 1 Cricula trifenestrata moth and Cocoon

reported to be predominant in India, Andaman, Myanmar, Vietnam, Cambodia, Malaysia, Singapore, Thailand, Bangladesh, Java, Philippines countries (Tikader et al. 2014; UK 2014).

Cricula trifenestrata takes up to 61-125 days to complete the life cycle. Complete defoliation occurs in 4th and 5 th instar. The larvae have 5 instars and passes 4 generation in a year (Tikader 2012; Huq et al. 1991). The average fecundity was reported to be $141.7 \pm 11.79$, and observed hatching rate was $88.81 \pm 1.37 \%$ when reared in Mangifera indica. The average Mangifera leaf consumption was about 29.4 g (Amin et al. 2008) Persea bombycina fed larvae (Figs. 3, 4) exhibited higher content of protein and lipid in the haemolymph suggesting Persea bombycina as the superior host in respect to silk deposition (Ghosh et al. 2015). High Infestation in Persea bombycina was observed during September to January (Ahmed et al. 2012). The efficiency of conversion of digested food in first instar when fed with Persea bombycina was $36.54 \%$ and the digestability was $67.74 \%$ indicating Persea bombycina as the preferred host plant by Cricula on the basis of nutritional indices. (Biswas et al. 2013). Cricula trifenestrata were even recorded, at an altitude of $1097 \mathrm{~m}$ in some parts of Tamilnadu (Singh 1992). In cashew, Cricula trifenestrata larval infestation had a positive correlation with number of flower and seeds (Siswanti et al. 2017).

In Sikkim, Cricula was reported infesting Cardamom i.e., Amomum subulatum causing huge devastation of the crop. The average fecundity was observed to be 157-252 eggs per month. The mature larvae is black-brown with red sublateral stripes, 2-11 somites with six setiferous tuburcles. Larval period ranges to $87.16+2.65$ days and larval mortality $23.23 \%$. Life cycle takes around 168.92 days (Yadav and Kumar 2004). The chromosome number $(n)$ of $C$. trifenestrata was found to be 31 (Narang and Gupta 1979). The cytochrome C oxidase subunit gene of Cricula trifenestrata was studied to identify specific unique sites for species identification to develop species marker. It was noted that 595 nucleotides are conserved in the species of cytochrome $\mathrm{C}$ oxidase gene. The 107th amino acid (valine) and 138th (threonine) were diagnostics amino acid for $C$. trifenestrata. The phylogentic study revealed that Cricula and Antherea share the same node of the saturnidae family suggesting monophyletic (Solihin et al. 2012).

\section{Control measures}

The Cricula infestation causes havoc destruction to the foliage hence researchers have studied various physical, 
Table 1 Host plant diversification of Cricula trifenestrata

\begin{tabular}{|c|c|c|c|}
\hline S. no & Botanical name & Family & Common name \\
\hline 1. & Mangifera indica & Anacardiaceae & Mango \\
\hline 2. & Persea bombycina /Machilus bombycina & Lauraceae & Som Sum, Mojali, Majti \\
\hline 3. & Anacardium occcidentale $L$ & Anacardiaceae & Cashew, caju \\
\hline 4. & Arachis hypogeal L & Fabaceae & Peanut, Groundnut, earthnut, monkey nut \\
\hline 5. & Cinnamomum cassia & Lauraceae & Chinese cassia, Chinese cinnamomum \\
\hline 6. & Litchicheinensis & Sapindaceae & Lychee, litchi \\
\hline 7. & Camellia sinensis & Theaceae & Tea \\
\hline 8. & Amomum subulatum & Zingiberaceae & $\begin{array}{l}\text { Black cardamom, Big cardamomum, hill cardamo- } \\
\text { mum, winged cardmomum }\end{array}$ \\
\hline 9. & Acrocarpus fraxinifolius & Fabaceae & $\begin{array}{l}\text { Pink cedar, Shingle tree, Australian Ash, Indian Ash, } \\
\text { Red cedar, Keny coffeeshade }\end{array}$ \\
\hline 10. & Bucklandia populnea & Hamamelidaceae & Dingdah, Pipli, Singliang \\
\hline 11. & Careya arborea & Lecythidaceae & Patana Oak, Wild Guava \\
\hline 12. & Schleichera trijuga & Sapindaceae & Lac tree, Ceylon oak, Kusum tree \\
\hline 13. & Ziziphus jujube & Rhamnaceae & Jujube, red date, Chinese date, Chinese jujube Bogari \\
\hline 14. & Piper nigrum & Piperaceae & Black pepper, kalimirch, golmirch \\
\hline 15. & Machilus odoratissima & Lauraceae & Fragrant Bay, \\
\hline 16. & Persea Americana & Lauraceae & Avacado \\
\hline 17. & Mimusops elengi & Sapotaceae & Spanish cherry, bullet wood, Maulsari, Bakull, Elengi \\
\hline 18. & Abelmoschus esculentus & Malvaceae & Okra, Ladys'finger \\
\hline 19. & Altingia excelsa & Hamamelidaceae & Rasamala, Oriental Sweet Gum, Shilarasa, Turushka \\
\hline 20. & Cinchona officinalis & Rubiaceae & Peruvian bark, quinine \\
\hline 21. & Cinnamomum verum & Lauraceae & Ceylon cinnamon, Dalchini, true cinnamon, lavanga \\
\hline 22. & Elaeocarpus floribundus Blume & Elaocarpaceae & Indian olive, Jalpai \\
\hline 23. & Litsea glutinosa & Lauraceae & Soft bolly gum, bolly beech, brown beech \\
\hline 24. & Luffa aegyptiaca & Cucurbitaceae & Sponge gourd, Ghia torai, loofa \\
\hline 25. & Ziziphus mauritiana & Rhamnaceae & Indian plum, Ber, elandai \\
\hline 26. & Syzygium cumini (L) & Myrtaceae & Java plum, jamun, black plum, naagai \\
\hline 27. & Spondias sps & Anacardiaceae & Hog Plum \\
\hline 28. & Bischofia trifoliata & Euphorbiaceae & Bishop wood \\
\hline 29. & Canarium harveyi & Burceraceae & Java almond, pili nut, pacific almond \\
\hline 30. & Malus floribunda Siebold ex Vanhoutte & Rosaceae & Crab apple, chokeberry \\
\hline
\end{tabular}

chemical and biological control methods to prevent infestation in field crops. Proper weeding of the tree cover in summer is seen effective to prevent to Cricula larval infestation in Cinchona plantations. This cultural operation serves as a first line of physical defence in preventing infestation (Van Zwet 1950). Biological control by utilizing parasitoid serves as an effective control measure in controlling the Cricula (Table 2). Parasitizaton of Cricula trifenestrata eggs with Telenomus sp has complete efficacy up to pupal stages of. Cricula trifenestrata, when parasitized with Brachymeria criculae efficacy resulted in $79.71 \%$. Mesomys orientalis and Sarcophaga $s p$. parasitoid can also control the Cricula infestation during pupal stage (Ali and Karim 1991). Xanthopimpla konowi parasitizes the pupae (Singh 1992). Brachymeria tibialis (Walker) parasitoid destroys and consumes the pupae inside the cocoon preventing future multiplication. Hence Brachymeria tibialis can be efficiently utilized as a biological control in Antherea assamensis silkworm rearing (Tikader 2012).

In Indonesia, Beauveria bassiana at a concentration of $5 \times 10^{6}$ spores suspension resulted in highest mortality of Cricula moth. However it is not effective in Antherea assamensis field (Sjafaruddin and Rahmatia 1999). Parasitoid Blepharipa zebina infest larvae of Cricula trifenestrata which infest Machilus bombycina (Negi et al. 1993). In Arunachal Pradesh Exorista sorbillans was observed as an endoparasitoid parasitizing the Cricula larvae and causing death at pupal stage during March to mid-September (Sarma et al. 2006). Chalcis cricula and C. etiplaeae parasitises Cricula larvae (Yadav and Kumar 2004). 


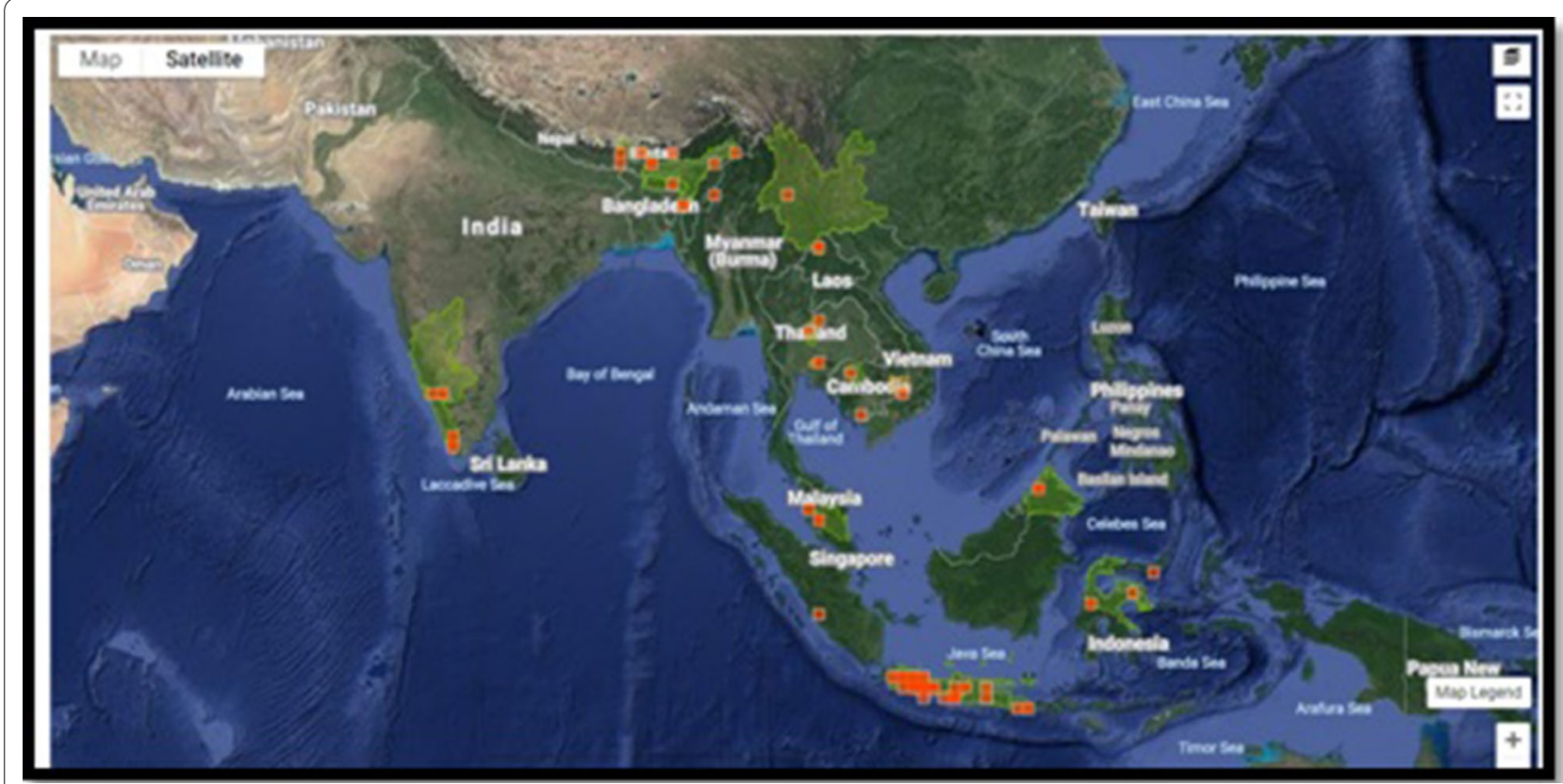

Fig. 2 Global distribution of Cricula trifenestrata. Source: https://www.inaturalist.org/taxa/510228-Cricula-trifenestrata

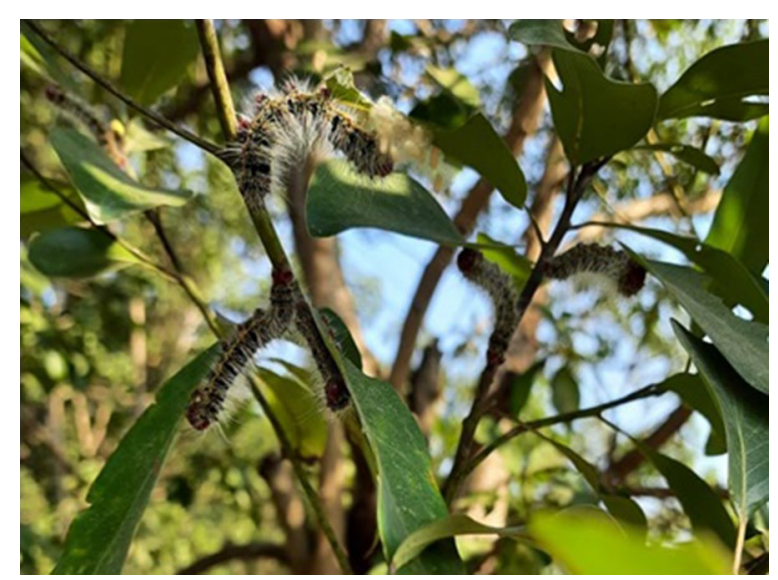

Fig. 3 Cricula trifenestrata infestation on Persea bombycina foliage

Fenvalerate and cypermethrin were the most effective chemical control methods, when treated for 7 days post treatment resulted in 94.44 and $79.16 \%$ larval mortality (Munaan 1986). In Maharastra field study has resulted in effective control of Cricula infestation in ground nut by cyhalothrin and Naled at 0.0005 and $0.001 \%$ (Deshmukh 1992) chemically infestation can be controlled by endosulphan, deltamethrin and neem based pesticide like azadirachtin $(0.003 \%$ and $0.015 \%)$ has been effective (Ahmed et al. 2012) $0.05 \%$ endosulfan and parathionmethyl was used to control (Singh 1992). 0.1\% methyl parathion and endosulphan are effective chemical control methods reported (Yadav and Kumar 2004).

\section{Methods}

The rearing parameters are reported in varied host plants. Here attempts on exploration of post cocoon parameters are explored for commercial utilization. Cocoons of Cricula trifenestrata which was reared upon consuming Persea bombycinia in the wild were obtained and the pupal and shell weight was determined. The cocoons were stifled in hot air oven at $45{ }^{\circ} \mathrm{C}$ for $2 \mathrm{~h}$. Owing to the presence of perforations in the cocoons reeling isa constrain hence it is utilized for spun yarn.

\section{Degumming and cake preparation}

The removal of sericin and letting the fibres loose for further processing is called Degumming. Cocoons of Cricula trifenestrata were degummed by boiling in $0.5 \%$ sodium carbonate for $45 \mathrm{~min}$. Further rinsing in hot distilled water and distilled cold water. Drying was done in hot air oven at $45^{\circ} \mathrm{C}$ for $2 \mathrm{~h}$.

$$
\text { Degumming loss }(\%)=W_{1}-W_{2} / W_{1}
$$

where $W_{1}$ is the initial weight of conditioned Cricula cocoons samples and $W_{2}$ is the weight of degummed as well as conditioned Cricula cocoons sample Followed by washing. The individual degummed cocoons were opened in water and sheets are formed and placed 

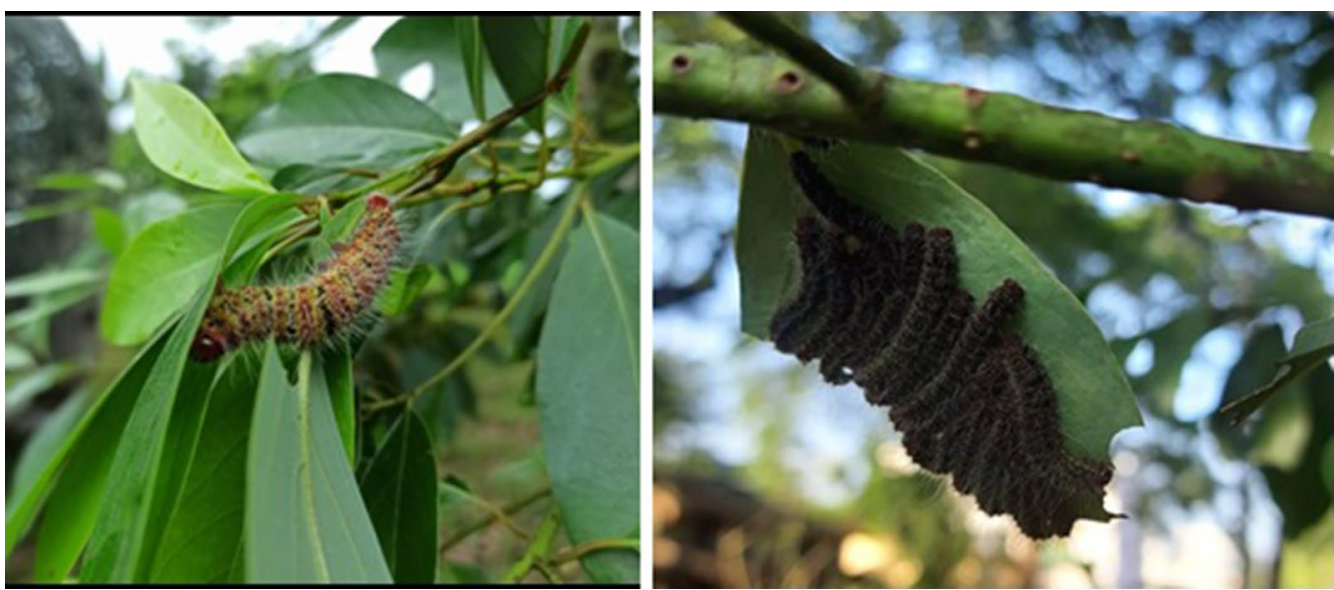

Fig. 4 Different stages of Cricula trifenestrata larval infestation in Persea bombycina host

Table 2 Reported Biological control of Cricula trifenestrata at different stages of rearing

\begin{tabular}{|c|c|c|c|c|}
\hline S. no & Parasitoid & Developmental stage & Efficiency & References \\
\hline 1. & Telenomus sp & Pupae/egg & $100 \%$ & Ali and Karim (1991) \\
\hline 2. & Brachymeria criculae & Pupae & $79.71 \%$ & \\
\hline 3. & Mesomys orientalis & Pupae & Not defined & \\
\hline 4. & Sarcophagasp & Pupae & & \\
\hline 5. & Brachymeria tibialis & Pupae & $25 \%$ & Tikader (2012) \\
\hline 6. & Chalcis cricula & larvae & Not defined & Yadav and Kumar (2004) \\
\hline 7. & Chalcis etiplaeae & larvae & & \\
\hline 8. & Xanthopimpla konowi & larvae & & Singh (1992) \\
\hline 9. & Beauveria bassiana & moth & $\begin{array}{l}\text { Spore suspension } \\
5 \times 10^{6}\end{array}$ & Sjafaruddin and Rahmatia (1999) \\
\hline 10. & Blepharipa zebina & larvae & Not defined & Negi et al. (1993) \\
\hline 11. & Exorista sorbillans & pupae & $13-14 \%$ & Sarma et al. (2006) \\
\hline 12. & Pediobius sp & pupae & $66.4 \%$ & Alam and Ahmed (1992) \\
\hline
\end{tabular}

overlapping. Cakes were prepared by overlapping 3-4 cocoon fibre sheets and dried in room temperature (Munshi et al. 2016).

\section{Spinning}

The yarn is spin in a motorized spinning machine. The silk ratio and silk recovery is determined.

\section{Results}

145 cocoons were obtained from the wild (Fig. 5). The post cocoon parameters were observed and analyzed and the results are shown in Table 3.

The total cocoon weight was observed to be 105 gm. wherein total shell weight was $15.5 \mathrm{gm}$ and total pupal weight was $89.5 \mathrm{gm}$. Single coccon weight, single shell weight and single pupal weight was $0.72 \mathrm{gm}$, $0.106 \mathrm{gm}$ and $0.617 \mathrm{gm}$ respectively. The silk ratio \% was $14.76 \%$. Shell weight after degumming was $14.5 \mathrm{gm}$. The
Degumming loss (\%) was found to be $6.45 \%$. The spun yarn weight was found to be $9.8 \mathrm{gm}$. and silk waste was $4.7 \mathrm{gm}$. Thereby determining that the silk recovery \% was $67.59 \%$ and Silk waste $\%$ was $32.41 \%$.

\section{Discussion Exploring the insights of commercial utilization of Cricula silk}

The cocoons were oval with tapering ends and contain perforation on the surface. When the cocoons were subjected to degumming the golden lusture was lost implying the affinity of the golden hue was high in the sericin content and not fibroin. Insights on developing an efficient degumming agent which aids in retaining the golden hue in the yarn may result in high demand of the fabric. The silk recovery \% was observed to be higher 


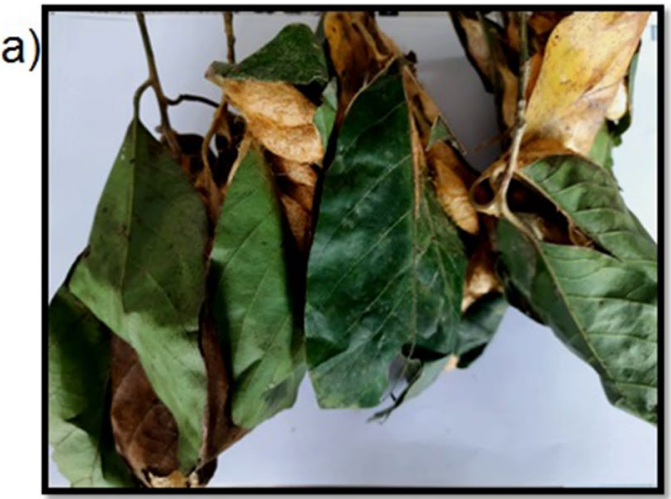

b)

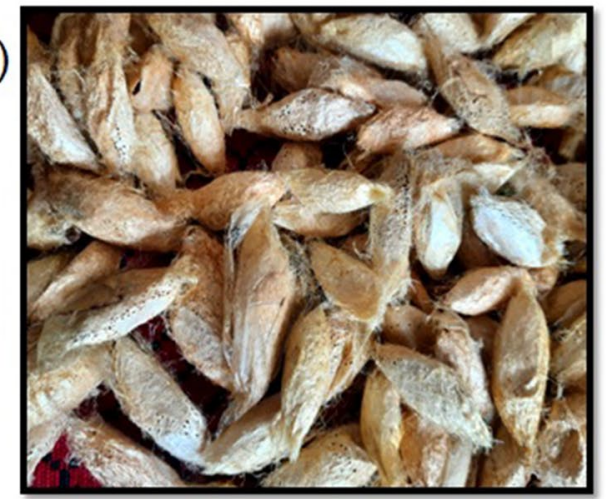

c)

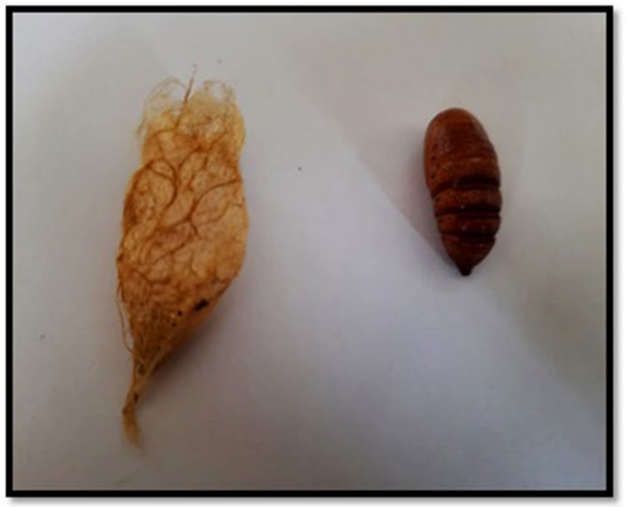

d)

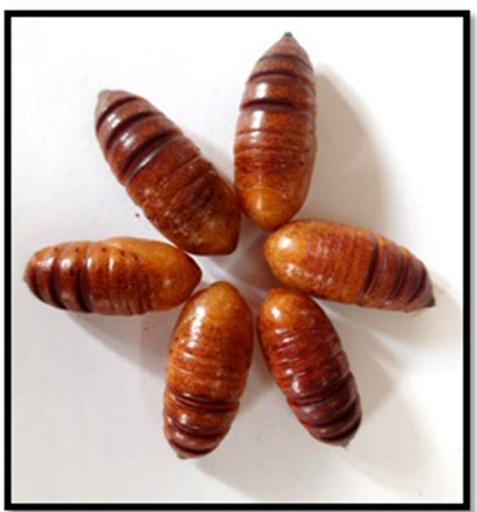

Fig. 5 a Spinned cocoons in leaves, $\mathbf{b}$ collected cocoons reared on Persea bombycina, $\mathbf{c}$ single cocoon and pupae, $\mathbf{d}$ matured pupa

Table 3 Post cocoon parameters determined in Cricula trifenestrata cocoon

\begin{tabular}{lll}
\hline S. no & Post cocoon parameters assessed & Results in $\mathbf{g m} / \%$ \\
\hline 1. & No. of cocoon & 145 \\
2. & Total Cocoon weight & $105 \mathrm{gm}$ \\
3. & Total shell weight & $15.5 \mathrm{gm}$ \\
4. & Total pupal weight & $89.5 \mathrm{gm}$ \\
5. & Single cocoon weight & $0.72 \mathrm{gm}$ \\
6. & Single shell weight & $0.106 \mathrm{gm}$ \\
7. & Single pupal weight & $0.617 \mathrm{gm}$ \\
8. & Silk ratio\% & $14.76 \%$ \\
9. & Shell weight after degumming & $14.5 \mathrm{gm}$ \\
10. & Spun yarn weight & $9.8 \mathrm{gm}$ \\
11. & Waste weight & $4.7 \mathrm{gm}$ \\
12. & Silk recovery\% & $67.59 \%$ \\
13. & Waste\% & $32.41 \%$ \\
\hline
\end{tabular}

than muga which was conventionally around $40-48 \%$ and higher yield was 55\% in Muga silk.

Cricula trifenestrata fibre was reported for the tensile strength and biocompatibility. The modulus elasticity of the single fiber of Cricula trifenestrata is about
$3681 \mathrm{MPa}$. The silk can be prepared by degumming method of boiling in $0.01 \mathrm{M} \mathrm{NaOH}$ for $1 \mathrm{~h}$. Degumming above the concentration $0.01 \mathrm{M} \mathrm{NaOH}$ resulted in hydrolysis of fibre. The ultimate tensile strength is obtained about $162 \mathrm{MPa}$ together with value of failure strain about 0.12 (Nindhia et al. 2014).

Unlike Bombyx mori, the pigments are usually deposited in the sericin which gets washed off during degumming process. However when cricula cocoons were degummed with chymotrypsin and the pigment content was observed in fibroin and sericin. It was observed that 1.4 times higher fold the pigment is present in fibroin than sericin (Yamada et al. 2001).

The wild silks in the world are still unexplored for their potential commercial utilization. Previous studies affirm the merits of Cricula silk for instance; C. trifenestrata silk protein was isolated and studied. The molecular mass of sericin and fibroin were $400 \mathrm{kDa}$ and $350 \mathrm{kDa}$ respectively, however fibroin when later underwent reduction the molecular mass was $180 \mathrm{kDa}$. The amino acid constituents resembled with higher serine content (Yamada and Tsubouchi 2001) The polar and non polar amino acid ratio in cricula sericin was about 69:31 (Manesa et al. 2020). Cricula trifenestrata Sericin has anti-proliferative 
a)

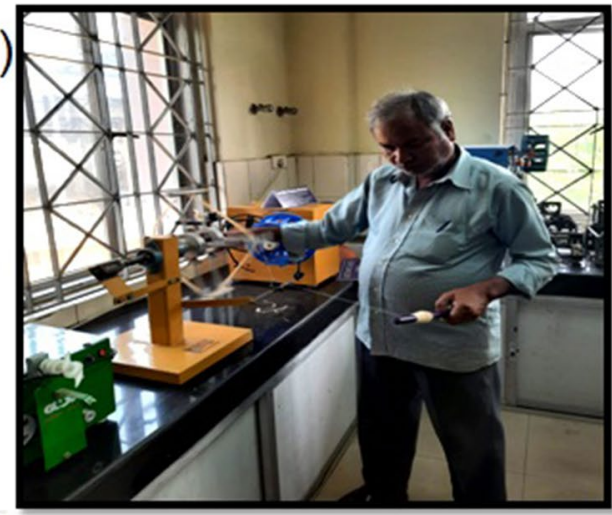

c)

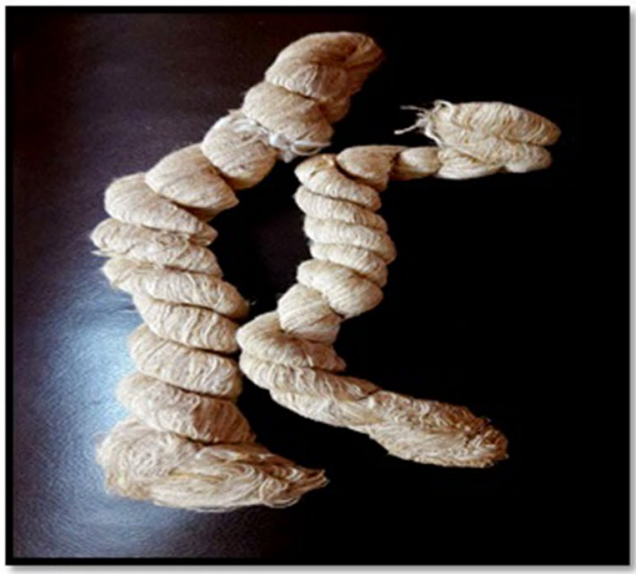

b)

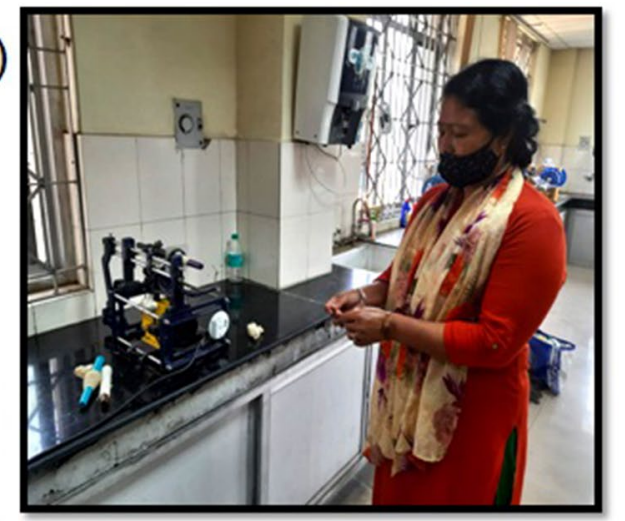

d)

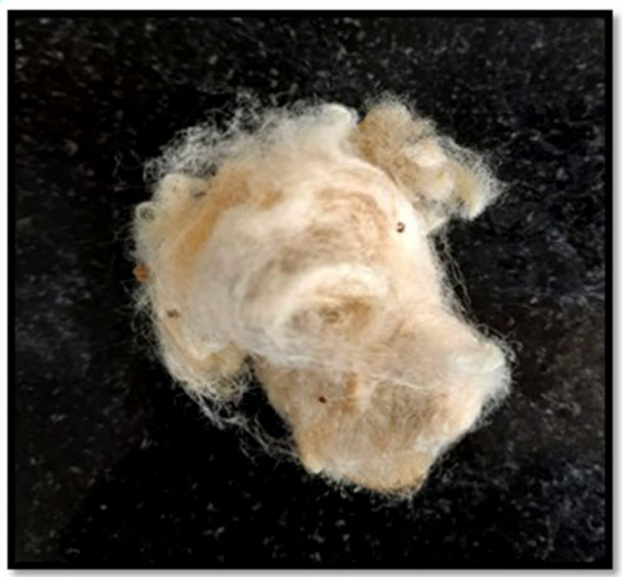

Fig. 6 a Degummed cocoon, b the yarn is spun in motorized spinning machine, c Spun yarn hank preparation on approvate, $\mathbf{d}$ cricula spun yarn

activity in feline kidney cells and Sericin-induced apoptosis (Liu et al. 2016). Cricula trifenestrata cocoon extract when treated on human fibroblasts revealed non cytotoxicty (Sunarintyas et al. 2012).

This study affirms the efficacy of Cricula to be utilized as a spun silk (Fig. 6). The golden cocoons are utilized as artifacts for attractive aesthetic products.

\section{Conclusions}

Popularization on the artistic utilization of these golden cocoons in fabric designing or any other products may be of high demand in the near future. In the current surge, Cricula sericin also has added biological effects in pharmaceuticals and cosmecutical industry. Hence more insights are to be explored for commercial product utilization of Cricula silk as a potential biomaterial, fabric, pharmaceutical, food, cosmetics and fuel industry.

\section{Abbreviations}

MT: Metric ton; $\mathrm{NaOH}$ : Sodium hydroxide; kDa: Kilo dalton; MPa: Mega pascal.

\section{Acknowledgements}

The authors wish to thank Central Silk Board, Bangalore, India for their constant support

\section{Authors' contributions}

$\mathrm{HH}$ and BNS conceived and designed the experiments. $\mathrm{HH}, \mathrm{MM}$ and SV performed the experiment and wrote the manuscript. PB and LG analyzed the data. LG and MM reviewed the manuscript. All authors have read and approved the manuscript.

\section{Funding}

No funding received from any organisation.

\section{Availability of data and material}

All data generated or analyzed during this study are included in this manuscript.

\section{Declarations}

Ethics approval and consent to participate Not applicable.

\section{Consent for publication}

The participants declare that the work has been consented for publication.

\section{Competing interests}

The authors declare that they have no competing interests. 


\section{Author details}

${ }^{1}$ Muga Eri Silkworm Seed Organisation, Ministry of Textiles, Central Silk Board, Guwahati, Assam, India. ${ }^{2}$ MESSO, P4 Seed Station, Mendipathar, Central Silk Board, North Garo Hills, Meghalaya, India. ${ }^{3}$ Regional Sericultural Textile Research Station, Central Silk Board, Guwahati, Assam, India.

Received: 19 September 2021 Accepted: 20 November 2021 Published online: 11 December 2021

\section{References}

Ahmed SA, Dutta LC, Sarmah MC (2012) Bio-efficacy of some insecticides against leaf eating caterpillar, Cricula trifenestrata Helfer (Lepidoptera: Saturniidae) Infesting Som, Persea bombycina Kost. Plantation Acad J Entomol 5(2):94-98

Alam MZ, Ahmed F (1992) Parasitoids associated with different stages of Cricula trifenestrata Helfer. Lepidoptera, Saturniidae

Ali MI, Karim MA (1991) Notes on the biology, behaviour and biocontrol agents of mango defoliator Cricula trifenestrata (Lepidoptera: Saturniidae). Bangl J Entomol 1:83-87

Amin MR, Ahad MA, Rono MMA, Tithi DA (2008) Life history traits of Cricula trifenestrata (Lepidoptera: Saturniidae) feeding on Mangifera indica. J Agrofor Environ 2(1):1-6

Biswas S, Hath TK, Ray N (2013) Effect of different host plants on nutritional indices of wild silk moth. Cricula Trifenestrata J Entomol Res 37(3):223-227

Deshmukh PB (1992) Efficacy of two insecticide treatments against aphid, Toxoptera avrantii, and caterpillar, Circula trifenesirata, on groundnut, Arachis hypogea L. Int Pest Control 34(5):153

Gharde SK, Chaudhuri N (2018) The life history and population growth parameters of leaf eating caterpillar Cricula trifenestrata Helfer (Lepidoptera: Saturniidae) infesting manochilus bombycina king. Int J Curr Microbiol App Sci 7(2):710-717

Ghosh J, Chaudhuri N, Bera C (2015) Bio-ecological analysis to identify the critical stage of development of mango defoliator Cricula trifenestrata (Lepidoptera: Saturniidae). Int J Recent Sci Res 6(10):7259-7262

Huq SB, Hossain M, Khan AB (1991) Biology of Cricula trifenestrata (Lepidoptera: Saturniidae), a leaf eating caterpillar of mango. Bangl J Entomol 1:19-26

Kaleka AS, Singh D, Saini S (2018) Further studies on the moth Cricula trifenestrata from North-West India (Lepidoptera: Saturniidae). Ann Entomol 20(1):15-17

Liu W, Karimazawa M, Ozaki T, An Y, Miyazaki M, Suzuki K, Tsutsumi KI, Yamashita T (2016) Cell proliferation inhibition by sericin from the wild silkworm. Cricula Trifenestrata Adv Biol Chem 6(1):28-33

Manesa KC, Kebede TG, Dube S, Nindi MM (2020) Profiling of Silk Sericin from cocoons of three Southern African Wild silk moths with a focus on their antimicrobial and antioxidant properties. Materials 13(24):5706

Munaan A (1986) Controlling Cricula trifenestrata Helf. on cashew trees. Pemberitaan Penelitian Tanaman Industri 12(1-2):36-40

Munshi R, Mazumdar S, Gupta PD, Chattopadhyay D (2016) Studies on standardization on degumming process for different eco races of eri silk cocoons. Indian J Nat Fibres 3(1):69-76

Narang RC, Gupta ML (1979) Chromosome number of Cricula trifenestrata Helfer (Lepidoptera: Saturniidae). Curr Sci 48(10):465-466

Negi BK, Barah A, Siddiqui AA, Sengupta AK (1993) Cricula trifenestrata (Lepidoptera: Saturniidae)-a new alternate host of Blepharipa zebina (Diptera: Tachinidae). In: Recent advances in Uzi fly research: proceedings of the national seminar on Uzi fly and its control, 16-17 January, 1992. Karnataka State Sericulture Development Institute, pp 269-271.

Nindhia TGT, Knejzlik Z, Ruml T, Nindhia TS (2014) Tensile properties and biocompatibility of indonesian wild silk Cricula trifenestrata: a preliminary study. J Med Bioeng 3(2):140-143

Sarma AK, Gupta MK, Singh KM (2006) New record of a dipteran endoparasitoid of Cricula trifenestrata Helfer on Som Machilus Bombycina. J Plant Protect Environ 3(1):143-144

Singh SP (1992) Frequent outbreaks of Cricula trifenestrata Helfer (Lepidoptera, Saturniidae) on mango. Indian J Plant Protect 20(1):114-115

Siswanti R, Supriyadi S, Subagiya S (2017) Correlation between damage plant by silkworm Cricula trifenestrata to cashew yield. Agrotechnol Res J $1(1): 21-27$
Sjafaruddin M, Rahmatia D (1999) Field trial of Beauveria bassiana to canarium moth (Cricula trifenestrata) on cashew crop. In: Seminar Nasional Hasil Pengkajian dan Penelitian Teknologi Pertanian Menghadapi Era Otonomi Daerah, Palu (Indonesia), 3-4 Nov 1999. PSE.

Solihin DD, Noor RR, Thohari AM (2012) The characteristics of cytochrome C oxidase gene subunit I in wild silkmoth Cricula trifenestrata helfer and its evaluation for species marker. Media Peternakan 35(2):102-102

Sunarintyas S, Siswomihardjo W, Tontowi AE (2012) Cytotoxicity of Cricula triphenestrata cocoon extract on human fibroblasts. Int J Biomater 2012:222-226

Tikader A (2012) New record of Brachymeria tibialis (Walker)(Hymenoptera: Chalcididae) on Cricula trifenestrata (Helfer) from India. J Mun Ent Zool $7(1): 222-225$

Tikader A, Vijayan K, Saratchandra B (2014) Cricula trifenestrata (Helfer) (Lepidoptera: Saturniidae)-A silk producing wild insect in India. Trop Lepidoptera Res 24:22-29

UK C (2014) Cricula trifenestrata ((Helfer)), tea flush worm.[pest/pathogen]. Cricula trifenestrata ((Helfer)), tea flush worm.[pest/pathogen]., (AQB CPC record).

Van Zwet AJ (1950) A practical method of cadavontrolling caterpillars in cinchona plantations. Bergcultures 19:331

Yadav S, Kumar A (2004) New record of wild silk caterpillar, cricula trifenestrata helfer on large cardamom and notes on it's biology. In: Arvind K (ed) Advances in Life Sciences, 1st edn, Chapter 36. p 305

Yamada $\mathrm{H}$, Tsubouchi $\mathrm{K}$ (2001) Characterization of silk proteins in the cocoon fibers of Cricula trifenestrata. Int J Wild Silkmoth Silk (jpn) 6:47-51

Yamada H, Kato Y, Tsubouchi K (2001) Yellow pigmentation of the fibroin core in the cocoon fibers of Cricula trifenestrata. Int J Wild Silkmoth Silk (jpn) 6:43-46

\section{Publisher's Note}

Springer Nature remains neutral with regard to jurisdictional claims in published maps and institutional affiliations.

\section{Submit your manuscript to a SpringerOpen ${ }^{\circ}$ journal and benefit from:}

- Convenient online submission

- Rigorous peer review

- Open access: articles freely available online

- High visibility within the field

Retaining the copyright to your article

Submit your next manuscript at springeropen.com 